\title{
The Influence of Hyperglycaemia, Hyperinsulinaemia and Genetic Background on the Fate of Intrasplenically Implanted Mouse Islets
}

\author{
A. Andersson \\ Department of Medical Cell Biology, Biomedicum, Uppsala University, Uppsala, Sweden
}

\begin{abstract}
Summary. We reported recently that intrasplenic transplantation of syngeneic pancreatic islets failed to cure obese-hyperglycaemic mice, despite a considerable growth of the grafted islets. In the present study, the role of sustained hyperglycaemia and hyperinsulinaemia for regeneration of transplanted islet cells was evaluated in these animals. Islets implanted into alloxan-diabetic $\mathrm{C} 57 \mathrm{BL} / 6 \mathrm{~J}$ mice in numbers insufficient to restore normoglycaemia did not grow. There was, however, a statistically significant correlation between the mean volume of implanted islets and the degree of normalization of hyperglycaemia. Insulin treatment of these suboptimally islet-implanted C57BL/6J mice resulted in a volume increase of the implanted islets. When corresponding experiments were undertaken with alloxan-diabetic $\mathrm{C} 57 \mathrm{BL} / \mathrm{KsJ}$ mice, no effect
\end{abstract}

was noted on hyperglycaemia and there was a drastic decrease in the volume of implanted islets. Islets implanted into old obese-hyperglycaemic mice that had returned to normoglycaemia but still were hyperinsulinaemic, decreased markedly in size. The present data suggest that neither hyperglycaemia nor hyperinsulinaemia per se are primarily responsible for the growth of islets in obese-hyperglycaemic mice. Furthermore, it is obvious that the genetic background is very important for morphological and functional responses of the islets to a prolonged period of hyperglycaemic stress.

Key words: Obese-hyperglycaemic mice, alloxan diabetes, intrasplenic islet transplantation, islet volume, serum glucose, serum insulin.
It was demonstrated recently that implantation of syngeneic islets failed to cure obese hyperglycaemic mice [1], in contrast to reports of previous studies [2-4]. This lack of effect on both hyperglycaemia and weight gain of young obese mice was evident despite a considerable growth of the intrasplenically implanted islets. It appears likely therefore, that factors responsible for the hyperplasia of endogenous islets of $o b / o b$ mice are to be found in the circulation, although Swenne and Bone [5] were unable to demonstrate a difference between serum from lean and obese mice in supporting a high rate of ${ }^{3} \mathrm{H}$-thymidine incorporation into DNA of fetal rat islets in vitro. Two possible factors, hyperglycaemia and hyperinsulinaemia have been investigated in this study, by observing the fate of syngeneic islets implanted in numbers insufficient to decrease the elevated blood glucose concentration of alloxan-diabetic recipients. By implanting islets into very old obese-hyperglycaemic mice ( $>1$ year old), at a stage of the syndrome when hyperglycaemia is normalized but hyperinsulinaemia is still marked [6], further information on the importance of each of these two factors might be gained. To detect possible effects of the genetic background, some of these studies were carried out with two different inbred mouse strains. One of these strains $(\mathrm{C} 57 \mathrm{BL} / 6 \mathrm{~J})$ is. known to have islets prone to regenerate when the diabetes mutation $(d b)$ is placed on this genetic background, whereas the other, $\mathrm{C} 57 \mathrm{BL} / \mathrm{KsJ}$, has islets which first exhibit hyperplastic changes and then degenerate under corresponding circumstances [7].

\section{Materials and Methods}

\begin{abstract}
Animals
Male and female inbred $\mathrm{C} 57 \mathrm{BL} / 6 \mathrm{~J}$ and $\mathrm{C} 57 \mathrm{BL} / \mathrm{KsJ}$ mice, aged 10-16 weeks (belonging to strains originally obtained from The Jackson Laboratory, Bar Harbor, Maine, USA) were used as islet donors. Males of both strains, injected IV with alloxan $(75 \mathrm{mg} / \mathrm{kg}$ body weight) or non-injected controls, served as islet recipients. Obese mice $(\mathrm{C} 57 \mathrm{BL} / 6 \mathrm{~J}(o b / o b)$ ), $>1$ year old, obtained by breeding mice heterozygous for the obesity gene $(+/ o b)$, also served as islet recipients. During the experimental period, animals were allowed free access to tap water and laboratory chow (Ewos-Anticimex, Type R3: Ewos, Södertälje, Sweden).
\end{abstract}


Table 1. Mean volume of intrasplenically implanted islets and serum glucose concentrations of two different strains of recipient mice, some of which had been treated with alloxan

\begin{tabular}{|c|c|c|c|c|c|c|c|}
\hline Mouse strain & $\mathrm{C} 57 \mathrm{BL} / 6 \mathrm{~J}$ & $\mathrm{C} 57 \mathrm{BL} / 6 \mathrm{~J}$ & $\mathrm{C} 57 \mathrm{BL} / 6 \mathrm{~J}$ & $\mathrm{C} 57 \mathrm{BL} / 6 \mathrm{~J}$ & $\mathrm{C} 57 \mathrm{BL} / \mathrm{KsJ}$ & $\mathrm{C} 57 \mathrm{BL} / \mathrm{KsJ}$ & $\mathrm{C} 57 \mathrm{BL} / \mathrm{KsJ}$ \\
\hline Alloxan-treatment & - & + & + & + & - & + & + \\
\hline Islet implantation & + & + & + & + & + & +++ & + \\
\hline Weeks of observation & 4 & 4 & 8 & 4 & 4 & 4 & 4 \\
\hline Insulin treatment & - & - & - & + & - & - & - \\
\hline $\begin{array}{l}\text { Mean islet volume } \\
\left(\mathrm{mm}^{3} \times 10^{-3}\right)\end{array}$ & $1.2 \pm 0.2(6)$ & $1.2 \pm 0.3(8)$ & $1.6 \pm 0.7(8)$ & $1.0 \pm 0.4(9)$ & $1.4 \pm 0.3(14)$ & $2.8 \pm 0.5^{\mathrm{a}}(4)$ & $0.5 \pm 0.1^{\mathrm{a}}(10)$ \\
\hline $\begin{array}{l}\text { Serum glucose before im- } \\
\text { plantation }(\mathrm{mmol} / \mathrm{l})\end{array}$ & - & $38.5 \pm 3.4(8)$ & $38.4 \pm 3.2(8)$ & $34.4 \pm 4.1(9)$ & - & $27.3 \pm 2.2(4)$ & $36.2 \pm 1.4(10)$ \\
\hline $\begin{array}{l}\text { Serum glucose at death } \\
(\mathrm{mmol} / \mathrm{l})\end{array}$ & $7.9 \pm 0.3(6)$ & $23.6 \pm 3.6^{\mathrm{b}}(8)$ & $25.5 \pm 4.7(8)$ & $15.2 \pm 2.9^{\mathrm{b}}(9)$ & $7.4 \pm 0.2(11)$ & $7.8 \pm 0.9^{c}(4)$ & $33.6 \pm 1.6(10)$ \\
\hline
\end{tabular}

Values are expressed as mean \pm SEM for the number of mice treated in parentheses. + and +++ under the subheading islet implantation denote implantation of approximately 150 or 500 syngeneic islets, respectively. ${ }^{a} p<0.05$ when compared with the value for islets implanted into control C57BL/KsJ mice. ${ }^{\mathrm{b}} p \leqslant 0.01$ and ${ }^{\mathrm{c}} p<0.001$ when compared with serum glucose values before islet implantation

\section{Chemicals}

Alloxan monohydrate was supplied by Sigma Chemicals, St. Louis, Missouri, USA. Collagenase was obtained from Worthington Biochemicals, Freehold, New Jersey, USA; Hanks' balanced salt solution from Statens Bakteriologiska Laboratorium, Stockholm, Sweden; ${ }^{125}$ I-labelled insulin from New England Nuclear, Dreieichenhain, FRG; antiserum against bovine insulin from Miles Laboratories, Kankakee, Illinois, USA; and crystalline mouse insulin from Novo, Copenhagen, Denmark.

\section{Islet Isolation and Implantation}

Pancreatic islets, prepared by a collagenase method [8], were obtained from either $\mathrm{C} 57 \mathrm{BL} / \mathrm{KsJ}$ or $\mathrm{C} 57 \mathrm{BL} / 6 \mathrm{~J}$ mice, which were starved overnight before the experiments. Groups of approximately 150 or 500 syngeneic islets were suspended in Hanks' solution and injected intrasplenically into lightly anaesthetized (ether) mice (alloxan-diabetic, obese or normal), via a microinfusion set. From all diabetic and obese animals, blood samples were collected for glucose determination by retroorbital puncture twice before islet implantation. Only alloxandiabetic mice with serum glucose concentrations $>22 \mathrm{mmol} / 1$ were used as recipients. Some of the alloxan-diabetic, islet-implanted $\mathrm{C} 57 \mathrm{BL} / 6 \mathrm{~J}$ mice were treated with insulin $(0.4 \mathrm{IU} /$ day) from the day of islet implantation. Every second week after the islet implantation, blood samples were collected as above until the end of the observation period ( 4 or 8 weeks). Serum glucose concentrations were determined with a glucose oxidase method using an automated analyser (Beckman Instruments, Fullerton, California, USA). Serum samples of the obese mice were analysed also for insulin content by means of a radioimmunoassay [9].

\section{Morphometry}

After killing the mice by cervical dislocation, their spleens were fixed in Bouin's solution, cmbedded, sectioned serially and stained with haematoxylin-eosin. The mean volume of the implanted islets was determined stereologically as previously described in detail [1]. Briefly, estimations were made in every third consecutive section of the area of randomly sampled islets (6-10 per animal). Weighed mean islet volumes were obtained by adding the volumes of the islet sections and correcting for the probability of choosing large islets.

\section{Statistical Analysis}

Results are expressed as mean \pm SEM. Probabilities ( $p$ ) of chance differences between the different groups were estimated by Student's two-tailed t-test [10].

\section{Results}

\section{Islet Implantation into Alloxan Diabetic Mice}

There was an almost identical mean volume of islets implanted intrasplenically into control mice of the two different strains (Table 1). Implantation of an insufficient number of islets (approximately 150) into two groups of alloxan-diabetic C57BL/6J mice resulted in a slight and, after 4 weeks, statistically significant reduction of the hyperglycaemia. Great variability was observed, however, between the different experimental animals and two mice from both experimental group (observed for 4 or 8 weeks) became normoglycaemic. No change in the mean intrasplenic islet volume was observed compared with the normal controls, but there was a statistically significant inverse correlation between the mean islet volume and serum glucose concentration at death in the mice observed for 8 weeks $(r=-0,81$; $p<0.01$ ). Insulin treatment of alloxan-diabetic, suboptimally islet-implanted C57BL/6J mice significantly decreased the serum glucose concentration but complete normalization was not achieved. No effect on the mean volume of implanted islets was observed.

In experiments utilizing alloxan diabetic C57BL/ $\mathrm{Ks} \mathbf{J}$ mice as recipients, implantation of a large number of islets (approximately 500) normalized serum glucose concentrations. Such islets increased twofold in volume during the 4-week observation period, in contrast to islets of the same strain implanted in smaller numbers (approximately 150), which did not affect the hyperglycaemia of the recipients. The mean intrasplenic volume of these particular islets decreased to one-third that of the control mouse islet implants.

\section{Islet Implantation into Old Obese-Hyperglycaemic Mice}

At this age ( $>1$ year old) the obese-hyperglycaemic syndrome was considerably attenuated. Thus, at the start of the experiments, the mean serum glucose 
Table 2. Mean volume of intrasplenically implanted islets and serum glucose and insulin concentrations of old ( $>1$ year) obese-hyperglycaemic mice $(\mathrm{C} 57 \mathrm{BL} / 6 \mathrm{~J} o b / o b)$

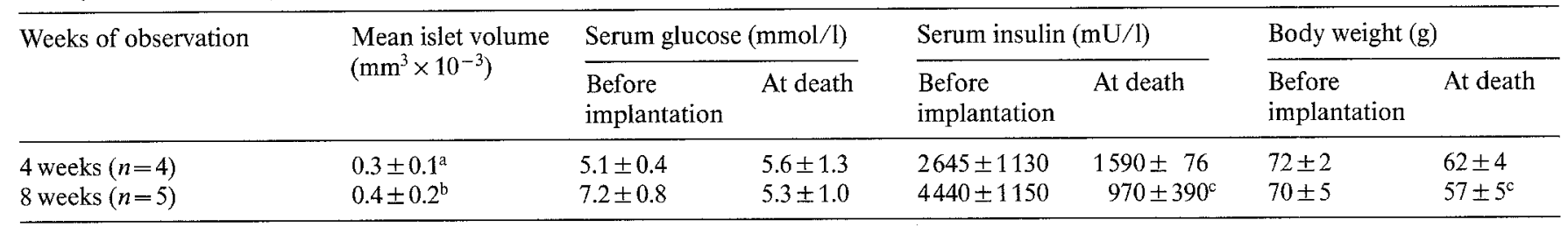

Values are expressed as mean \pm SEM. $^{a} p<0.01$ and ${ }^{b} p<0.05$ when compared with the mean islet volume value for intrasplenic islets of control $\mathrm{C} 57 \mathrm{BL} / 6 \mathrm{~J}$ mice. ${ }^{\mathrm{C}} p<0.05$ when compared with the body weight or serum insulin concentration before islet implantation (paired t-test)

concentration of the animals was only $6.3 \pm 0.6 \mathrm{mmol} / 1$ $(n=9)$. The hyperinsulinaemia, however, was still markedly increased $(3660 \pm 830 \mathrm{mU} / 1 ; n=9$; the corresponding control value for lean $\mathrm{C} 57 \mathrm{BL} / 6 \mathrm{~J}$ mice was $25-50 \mathrm{mU} / 1)$ and so was the body weight $(71 \pm 3 \mathrm{~g}$; $n=9$ ). Intrasplenic implantation of 500 islets did not significantly affect any of these variables (Table 2), except for a slight decrease of serum insulin concentration and body weight of mice observed for 8 weeks. The intrasplenic islets of both groups of mice (observed for 4 or 8 weeks) decreased in size to one-third or one-quarter that of lean control C57BL/6J mice (Table 1). Recent studies in this laboratory on the development of the obese-hyperglycaemic syndrome have shown that a decrease of body weight down to normal values occurs during the second year of life and the same holds true for the serum insulin concentration [6].

\section{Discussion}

The present findings indicate that neither hyperglycaemia nor hyperinsulinaemia alone can be the cause of marked hypertrophia of islets implanted intrasplenically into young obese-hyperglycaemic mice. Thus, a prolonged hyperglycaemic stress with concomitant hypoinsulinaemia on islets implanted in insufficient number, caused either a lack of growth $(\mathrm{C} 57 \mathrm{BL} / 6 \mathrm{~J})$ or a considerable islet volume reduction $(\mathrm{C} 57 \mathrm{BL} / \mathrm{KsJ})$. Likewise, hyperinsulinaemia accompanied by normal or even subnormal serum glucose concentrations as in the old obese mice, resulted in a decrease of the mean volume of implanted islets. The fact that alloxan-diabetic C57BL/6J mice (which in this study became normoglycaemic after implantation of a low number of islets, displayed the largest intrasplenic islets, indicates that sufficient insulin must be produced by the grafted islets, before islet growth takes place. In support of this conclusion, islets implanted in sufficient numbers (i. e. normoglycaemia was achieved) into alloxan-diabetic mice of both strains, grow twice as much as islets implanted into normal mice [1]. McEvoy and Hegre [11] also have shown that insulin treatment of alloxan-diabetic rats with fetal pancreatic glands implanted under the renal capsule, resulted in a two- to threefold increase of the B cell mass. These results were confirmed recently by
Brown et al. [12], who demonstrated that, with prolonged insulin treatment, one single fetal rat pancreas could completely reverse diabetes in an adult rat. There is also good evidence to indicate that insulin supplementation of tissue culture medium enhances replication of cultured fetal or neonatal rat islet cells $[13,14]$. In the present study treatment of insufficiently islet-implanted C57BL/6J-mice with daily injections of insulin did not affect the mean volume of the grafted islets. Since only partial normalization of the hyperglycaemia was achieved, due to difficulties in treating mice with exogenous insulin, it may be speculated that the serum insulin values of these particular mice were too low to influence islet cell replication.

Taken together, the present data suggest that a combination of hyperglycaemia and hyperinsulinaemia contribute to the growth of islets implanted intrasplenically into non-senescent obese-hyperglycaemic mice as reported recently [1]. It cannot, however, be ruled out that other factors, present in younger animals, also are involved in this process.

The experiments carried out with the $\mathrm{C} 57 \mathrm{BL} / \mathrm{KsJ}$ mice clearly demonstrate the importance of the genetic background for morphological and functional response of islets of Langerhans to a prolonged hyperglycaemic stress. Obviously, the islet cells of this strain are capable of replication when challenged with high glucose, as evidenced by the islet growth of the mice treated and "cured" by a sufficient number of islets. If the functional stress is prolonged over several weeks, however, a clear cut reduction of the islet volume will occur. Whether this islet cell loss is due to a restriction in replicative capacity or a tendency to exhaustion under these circumstances is unclear. The fact that when the diabetes mutant gene is placed on the $\mathrm{C} 57 \mathrm{BL} / \mathrm{KsJ}$ background the islet cells can compensate for increased functional demands early in the syndrome, but that later islet atrophy occurs concomitant with the development of the fulminant diabetes syndrome [15] is in favour of the "exhaustion" theory. Ongoing experiments in vitro and in vivo, hopefully will further elucidate this question.

Acknowledgements. The skilled technical assistance of A.B. Andersson, C. Bittkowski, M.Engkvist, E. Forsbeck and A. Nordin is gratefully acknowledged. Financial support was received from the Swedish Medical Research Council (12X-109; 16X-4527), the Swedish Diabe- 
tes Association, The Kroc Foundation and the Nordic Insulin Fund. Parts of the results of this study were read at the 17th Annual Meeting of EASD, Amsterdam, 15-18 September 1981.

\section{References}

1. Andersson A, Eriksson U, Petersson B, Reibring L, Swenne I (1981) Failure of successful intrasplenic transplantation of islets from lean mice to cure obese-hyperglycaemic mice, despite islet growth. Diabetologia 20: 237-241

2. Strautz RL (1970) Studies of hereditary-obese mice (ob/ob) after implantation of pancreatic islets in millipore filter capsules. Diabetologia $6: 306-312$

3. Gates RJ, Hunt MJ, Smith R, Lazarus NR (1972) Return to normal of blood-glucose, plasma-insulin, and weight gain in New Zealand obese mice after implantation of islets of Langerhans. Lancet 2: 250-253

4. Gates RJ, Hunt MJ, Lazarus NR (1974) Further studies on the amelioration of the characteristics of New Zealand obese (NZO) mice following implantation of islets of Langerhans. Diabetologia 10: $401-406$

5. Swenne I, Bone AJ (1981) Effects, in tissue culture, of serum from obese mice on the DNA synthesis of the pancreatic B cell. Cell Biol Int Rep 5: 647-652

6. Westman $S$ (1968) Development of the obese-hyperglycaemic syndrome in mice. Diabetologia 4: 141-149

7. Coleman DL (1978) Obese and diabetes: two mutant genes causing diabetes-obesity syndromes in mice. Diabetologia 14: 141-148

8. Howell SL, Taylor KW (1968) Potassium ions and the secretion of insulin by islets of Langerhans incubated in vitro. Biochem $\mathbf{J} 108$ : $17-24$

9. Heding LG (1972) Determination of total serum insulin in insulintreated patients. Diabetologia 8: 260-266

10. Ostle B (1963) Statistics in research, 2nd ed. Ames, The Iowa State University Press

11. McEvoy RC, Hegre OD (1978) Syngeneic transplantation of fetal rat pancreas. II. Effect of insulin treatment on the growth and differentiation of pancreatic implants fifteen days after transplantation. Diabetes 27:988-995

12. Brown J, Heininger D, Kuret J, Mullen Y (1981) Islet cell growth after transplantation of fetal pancreas and control of diabetes. Diabetes 30: 9-13

13. McEvoy RC (1981) Fetal rat pancreas in organ culture: Effect of exogenous insulin on the development of islet cells. Horm Metab Res 13: 5-8

14. Rabinovitch A, Quigley C, Russell T, Patel Y, Mintz DH (1982) Insulin and multiplication stimulating activity (an insulin-like growth factor) stimulate islet $B$ cell replication in neonatal rat pancreatic monolayer cultures. Diabetes 31: 160-164

15. Coleman DL, Hummel KP (1967) Studies with the mutation, diabetes, in the mouse. Diabetologia 3:238-248

Received: 4 February 1983

and in revised form: 9 May 1983

Dr. A. Andersson

Department of Medical Cell Biology

Biomedicum

P.O. Box 571

S-751 23 Uppsala

Sweden 